Corruption and satisfaction with democracy: The conditional role of electoral disproportionality and ballot control

\author{
Alessandro Pellegata \\ Department of Social and Political Sciences \\ Università degli Studi di Milano \\ Via Conservatorio, 7 \\ 20122 Milano (Italy) \\ Tel. +390250321221 \\ Fax +390250321240 \\ alessandro.pellegata@unimi.it (corresponding author)

\section{Vincenzo Memoli} \\ Department of Political and Social Sciences \\ Università degli Studi di Catania \\ Via Vittorio Emanuele II, 8 \\ 95131 Catania (Italy) \\ Tel. +39095 7347205 \\ Fax +39095 70305246 \\ memoli@unict.it
}

Published online ahead of print in European Political Science Review on 8 January $\underline{2018}$ 


\title{
Corruption and satisfaction with democracy: The conditional role of electoral disproportionality and ballot control
}

\begin{abstract}
Existing literature has analysed the relationship between electoral systems and either corruption or satisfaction with democracy (SWD) focusing on the traditional distinction between majoritarian and proportional systems. This paper, instead, investigates if and how specific aspects of electoral systems mediate the negative effects of corruption perceptions on SWD. We argue that two mechanisms act simultaneously but at different levels. The first mechanism is the relationship between voters and the national government, while the second links single representatives to their constituents. We advance conditional hypotheses that postulate an attenuating effect of disproportionality and a reinforcing impact of personal vote. Empirical results from 35 elections in 33 democracies, using both individual and aggregate level data, confirm the research hypotheses. More disproportional electoral systems weaken the impact of citizens' perceived corruption on their democratic satisfaction, while this is strengthened by systems in which the ballot control is mostly in the hand of the voters.
\end{abstract}

Keywords: corruption; disproportionality; electoral systems; ballot control; satisfaction with democracy. 


\section{Introduction}

Recently, satisfaction with democracy (SWD) has received increasing attention in comparative politics. Much has been written about the important consequences of this indicator on regime stability and perceived legitimacy in the eyes of citizens (see Seligson, 2002; Sarsfield and Echegaray, 2005).

Although SWD is a complex and multifaceted concept (Linde and Ekman, 2003), the literature commonly interprets it as an indicator of what Easton $(1965 ; 1975)$ has defined as "specific support", and in particular what Norris (1999a) has named "regime performance". SWD implies a citizens' evaluation of the way the democratic process effectively works. Not surprisingly, several recent studies have empirically detected a highly significant and negative association between the quality of the governance of a country, and in particular the level of corruption in the public sector, and SWD (Anderson and Tverdova, 2003; Wagner et al. 2009; Dahlberg and Holmberg, 2014; Dahlberg et al. 2015; Dahlberg and Linde, 2016).

Public opinion data, such as the Comparative Study of the Electoral Systems (CSES) adopted in this study, generally confirm that countries in which the share of respondents satisfied with democracy is very low also tend to present the highest proportions of citizens that perceive widespread political corruption. At the same time, survey data show important variations that deviate from this general pattern and highlight an interesting puzzle that is worth explaining. Approximately 90 percent of the respondents in Israel (2003) and Italy (2006) perceived corruption as widespread in their country public sector, and only approximately 35 percent of them were satisfied with the functioning of democracy. However, although 83 percent of French respondents in 2002 perceived widespread corruption, 56 percent of them were satisfied with democracy. In the same way, in Japan (2004), 90 percent of respondents perceiving 
corruption coexisted with 71 percent of citizens expressing democratic satisfaction, and in Ireland (2002), even though 73 percent of respondents perceived widespread corruption, an impressive 81 percent of them were satisfied.

Several cultural, economic and contextual specific factors may explain this heterogeneity, but previous studies have found little support for these explanations (Mishler and Rose, 2001; Chang and Chu, 2006). In the present article, we focus our attention on the role played by institutions, in particular electoral systems, in mediating the relationship between perceived corruption and SWD. At the time the CSES surveys were conducted, for instance, Israel and Italy adopted closed-list PR systems based on large districts that favour party fragmentation, while France, Ireland and Japan adopted different PR, majoritarian or mixed systems that generate disproportional results and offered voters the possibility to influence the candidates' chance of being elected. Thus, we advance two conditional hypotheses that contrast an effect of electoral disproportionality in attenuating the impact of perceived corruption on SWD to a strengthening role played by the ballot structure. These hypotheses rest on causal mechanisms that operate simultaneously but at different levels. Vote-seat disproportionality stresses the relation of accountability between national governments and the voters, while ballot control affects the relationship between representatives and their constituents.

Hypotheses are tested making use of the Module 2 (2001-2006) of the CSES dataset on a sample of more than 29,000 respondents surveyed at the time of 35 elections conducted in 33 consolidated and newly established democracies. ${ }^{1}$ Our main

\footnotetext{
${ }^{1}$ The data and documentation can be downloaded from http://www.cses.org/. Unfortunately, we could not use Modules 1 (1996-2001), 3 (2006-2011) and the first release of Module 4 (2011-2016) of the CSES
} 
findings confirm the two research hypotheses advanced and are robust to the inclusion of several control variables at both the individual and country levels and to different robustness checks.

We believe that for several reasons this study represents an important contribution to the existing literature on the relationship between perceived corruption and SWD and the role of electoral institutions in affecting it. First, different studies analysed the direct effects of electoral systems on SWD but produced inconclusive results. The beneficial consequence of adopting PR systems in enhancing SWD, emphasized by several scholars (Lijphart, 1999; Bernauer and Vatter, 2012), has been opposed by other works emphasizing a more important role played by majoritarian systems (Norris, 1999b; Karp and Bowler, 2001; Aarts and Thomassen, 2008). Other scholars have argued, instead, that electoral systems have indirect effects on SWD through the quality of representation, the clarity of responsibility of governments or the ideological congruence between voters and parties or governments (Warwick, 1994; Lijphart, 1999; Norris, 2004; Tavits, 2007). However, our study takes a step forward by combining two streams of literature on the determinants of SWD that have been usually analysed separately; one regarding the input side of the democratic process, i.e., the electoral dimension, and the other concerning the output side, i.e., the quality of governance (Dahlberg and Holmberg, 2014; Dahlberg et al., 2015). More precisely, this article demonstrates how different features of electoral systems, which pertain to the input side of the democratic process, moderate the impact of corruption, one of the most detrimental factors of democratic satisfaction that is related to the output side of the democratic process.

dataset because these do not include a specific question regarding the respondents' perceived level of corruption. 
Furthermore, whereas most of the previous studies have considered the traditional distinction between Westminster and consensual democracies or majoritarian and proportional electoral systems, we think that focusing on the general institutional framework may be misleading for three main reasons. First, the majoritarianproportional division is not able to seize the high variability in magnitude, proportionality and ballot structure displayed by different PR systems. Second, this distinction cannot adequately classify the eight mixed-member electoral systems present in our sample. Finally, several authors have demonstrated that electoral systems are the result of somewhat different combinations of various elements that can present contrasting effects on both corruption control and political support (see Lijphart, 1994; Farrell, 2001; Rae, 1967). This suggests postulating contrasting mediating effects of different features that together determine an electoral system.

Finally, different from a recent study (Xezonakis et al., 2016) that considers the mediating role of electoral institutions on the relationship between perceived corruption and incumbent voting, we focus on SWD. We argue that electoral institutions affect not only the voters' decision to reward or punish corrupt politicians but also their satisfaction with the functioning of democracy. By making the possibility of alternation in government more concrete and the relationship between representatives and their constituents closer, increasing the monitoring capacities of voters and opponents, different electoral systems affect how and how much voters take into consideration their perceptions of corruption in evaluating the performance of the democratic process. More precisely, specific aspects of the electoral systems provide diverse psychological and objective incentives that affect citizens' democratic satisfaction.

The paper is structured as follows. In the second section, we illustrate the relationship between perceived corruption and SWD, while in the third section we 
elaborate the main theoretical framework and advance the research hypotheses. In the fourth section, we describe the sample of countries analysed, the data and the methodology used, while in the following section, we discuss the empirical results obtained from our analyses. Finally, in the last section, we present the most important conclusions we can draw from our research.

\section{The relationship between perceived corruption and SWD}

Easton's $(1965 ; 1975)$ analytical framework distinguishes between different levels of political support. A more abstract level named "diffuse support" refers to the citizens' support of a political regime as an ideal. "Specific support", instead, denotes the citizens' attitude towards the decisions and general performance of a political system. According to the Eastonian model, political support can be addressed towards the community, such as the nation, the regime, meaning the performance of the democratic systems, or the authorities, such as specific institutions and political actors. Previous studies showed that citizens are able to discern between these different levels and, while being highly supportive of democracy as a political regime, they might express dissatisfaction with the way the democratic process works in their country and distrust the government and the parliament (Klingemann, 1999; Norris, 1999a; Linde and Ekman, 2003).

In this study, we focus our interest on the support for the democratic process, which Norris (1999a) named "regime performance". Several empirical studies have demonstrated that corruption strongly and negatively affects citizens' attitudes towards the democratic process and institutions (see Mishler and Rose, 2001; Anderson and Tverdova, 2003; Chang and Chu, 2006; Dahlberg et al., 2015). A narrow definition that is commonly adopted in comparative studies considers corruption as "the misuse of 
public office for private financial gains" (among others, Rose-Ackerman, 1999).

Although there are different activities that can be qualified as corrupt, each of them typically involves elected officials and/or appointed bureaucrats who abuse the power and authority with which they have been entrusted for private gain. Such activities occur at the expense of the collective community, thereby violating the norms that regulate public office. When public servants are committed to extracting illicit rents from their privileged positions, human, social and economic resources are diverted from the public interest, undermining the principles of democratic accountability and fairness and the impartiality of political institutions (della Porta, 2000; Rothstein and Teorell, 2008). Several detrimental consequences of corruption contribute to undermining political support. Corruption radically distorts public demand, privileging the satisfaction of the so-called "internal demand", i.e., those people who participate in corrupt exchanges. It increases the costs of the public administration because both corruptor and corrupted share an interest in having the cost of bribery drawn from the public purse to widen the margin of gain (della Porta, 2000). Moreover, corruption delays the completion of public good and reduces the productivity of firms that interact with the state. Using the language of the principal-agent theory, corruption is a source of "agency loss" (Lupia, 2003). The principal (the citizen) is damaged because an agent (the public official) lacks the skill or incentive to complete the task delegated to her/him. This implies that the public is compelled to pay the externalities of this misallocation process. Thus, corrupt institutions denote inefficient institutions that lose their credibility in the eyes of the citizens and contribute to generate disaffection and mistrust towards the functioning of democracy. When corruption is perceived as endemic in a political system, a vicious circle emerges in which corruption and mistrust reinforce each other, generating a spiral of cynicism among citizens (Melgar at al., 2010). 
The operationalization of both SWD and corruption is not an easy task, and it is strictly intertwined with the core meaning of these two concepts. This is why measurement issues related to these two phenomena have been highly debated in the literature. Module 2 (2001-2006) of the CSES has the advantage of including survey questions that operationalize both SWD and perceived corruption. The former is a question that is commonly used in comparative politics to measure citizens' support for the democratic process and reads as follows: "On the whole, are you very satisfied (1), fairly satisfied (2), not very satisfied (3) or not at all satisfied (4) with the way democracy works in [country]?”. Linde and Ekman (2003) have shown that this question measures citizens' attitudes towards the way a democratic system works in practice, instead of their opinions on the goodness of democracy as a political regime.

Corruption is measured by the respondents' answers to the following question: "How widespread do you think corruption such as bribe taking is amongst politicians in [country]?: very widespread (1), quite widespread (2), not very widespread (3), it hardly happens at all (4)". Given the clandestine nature of corruption, it is very difficult, if not impossible, to obtain objective measures that are valid and reliable in cross-national analyses. Thus, existing literature often relies on perception-based indicators of corruption. Most of these studies adopt measures of corruption developed on experts' perceptions, but several recent works have adopted indicators based on perceptions of the general public (Charron, 2015; Clausen et al., 2011; Pellegata and Memoli, 2016).

Measuring corruption with mass perceptions presents several shortcomings. Common citizens may not be really informed about the actual spread of corruption in the public sector of their country. Their opinions are not necessarily driven by a direct experience with bribery, but rather by exogenous factors, such as the media, the 
ideology of their government or its political and economic performance (Treisman, 2007; Mishler and Rose, 2008). Moreover, relying on individual perceptions, the risk of endogeneity with citizens' satisfaction with democracy increases. Citizens may be induced to report corruption among politicians just because they are dissatisfied with the way the democratic process works.

However, there are several good reasons to think that citizens' perceptions represent a valid indicator of political corruption and play a significant role in forming their attitudes towards the political authorities. Reported experiences with cases of corruption refer to a dimension of corruption that is different from the aspect reflected by perception-based indicators. Experience-based measures tend to capture street-level or "petty" corruption, which most of the time originates in interactions that citizens have with low-level public officials, such as desk officers or police officers. Citizens' perceptions of corruption instead explicitly refer to the "grand" corruption that infects national politicians and the highest levels of government (Mishler and Rose, 2008). This is a type of corruption that most citizens have never encountered but presumably represents one of the most important factors that influence the citizens' degree of satisfaction with the way the democratic process works in their country. Citizens' perceptions of the level of corruption among politicians of their country, even though it is not certain whether they reflect the real spread of corruption in the public sector, are precisely what we are interested in measuring in this study. Actually, in most mature democracies, citizens tend to perceive corruption as being quite widespread, but at the same time, they usually report very few direct experiences with bribery. ${ }^{2}$ This

\footnotetext{
2 The first EU Anti-Corruption report published by the EU Commission at the beginning of 2014 shows that 76 percent of respondents perceived political corruption as a quite or very widespread phenomenon, but only 8 percent of them declared to have had a direct experience with a corruption episode. For the
} 
divergence could be explained by the fact that citizens are reluctant to report their direct experiences with corruption, weakening the reliability of expert-based measures. Nevertheless, Charron (2015) demonstrated that perceptions of how much a country's public sector is plagued by corruption among those citizens who have not recently experienced corruption first-hand are highly consistent with the perceptions of those who report to have experienced one or more cases. Finally, a few recent studies have demonstrated that, even though direct experiences with bribes impact citizens' attitudes towards political authorities, people's perceptions of corruption remain a significant explanatory factor (Treisman, 2007; Clausen et al., 2011). ${ }^{3}$

Figure 1 plots a bar chart showing the percentage of people in each sample country that are fairly or very satisfied with democracy and the percentage of people that perceive political corruption as a quite or very widespread phenomenon. As we can see, Figure 1 displays a high cross-national variation for both variables. The graph confirms on the entire sample what we have already highlighted with some examples in the introduction. Countries with the lowest proportion of people satisfied with democracy also present high levels of perceived corruption. At the same time, in several countries, a broad percentage of people perceiving widespread political corruption coexist with quite high levels of political support.

documentation and data see http://ec.europa.eu/dgs/home-affairs/what-we-do/policies/organized-crimeand-human-trafficking/corruption/anti-corruption-report/index_en.htm. This difference also emerges using data from the Global Corruption Barometer survey (http://www.transparency.org/research/gcb/).

${ }^{3}$ Unfortunately, the CSES Module 2 dataset does not include a question on citizens' direct experiences with bribery. Otherwise, it would have been interesting to re-test our hypotheses using this indicator of corruption. 
Figure 1 about here

\section{The moderating role of the electoral systems}

We argue that electoral institutions contribute to explaining the cross-country heterogeneity in the association between individual perceptions of corruption and the degree of satisfaction with the way democracy works.

One influential stream of literature investigated the role played by the electoral systems in affecting SWD. However, the empirical findings are unclear and somehow contradictory. Lijphart (1999) and Bernauer and Vatter (2012) argued that PR systems help to foster citizens' democratic satisfaction. In contrast, Norris (1999b), Karp and Bowler (2001) and Aarts and Thomassen (2008) have suggested that majoritarian systems are associated with higher levels of political support. Other studies, instead, postulated an indirect impact of electoral institutions on SWD through their role in fostering aspects such as the clarity of responsibility and accountability of governments, the quality of representation or the ideological congruence between voters and parties or governments (Warwick, 1994; Lijphart, 1999; Norris, 2004; Tavits, 2007). This study takes a step further in increasing our knowledge on the conditional effects of electoral institutions by focusing on one of their so-far neglected political consequences. We expect that different features of the electoral systems, which contribute to the structure of the input side of the democratic process, play a significant role in mediating the impact of citizens' perceptions of an output side aspect, such as corruption, on SWD. In the presence of specific aspects of electoral systems, citizens may take more or less into consideration in their perceptions of how corruption is widespread among politicians when evaluating how satisfied they are with the democratic process in their country. 
In particular, we focus on vote-seat disproportionality (and the district magnitude that mostly contributes to it) and the ballot structure of an electoral system. We advance plausible theoretical arguments that contrast an attenuating effect of electoral disproportionality on the impact of perceived corruption on SWD and alternatively a reinforcing role played by the ballot control. These opposite arguments emphasize different causal mechanisms that operate at different levels. One mechanism acts to strengthen government accountability through elections, the other affects the relationship that links representatives to their constituents.

More disproportional systems tend to generate a bilateral party competition between two major parties and durable single-party governments (Warwick, 1994, 2011; Lijphart, 1999). A political-institutional framework of that kind is characterized by higher clarity of responsibility, which creates easier opportunities for voters to evaluate the performance of the decision makers and eventually punish those that are perceived as corrupt by voting retrospectively (Powell, 2000; Tavits, 2007). Using the words of Kaiser and colleagues (2002, 317-319), high levels of electoral disproportionality increase the responsibility of an institutional regime, an element that they conceptualize with the "chance of alternation" in government. The possibility of alternation is maximized by highly disproportional systems because they translate even relatively small changes in votes into substantial shifts at the legislative level. Even though citizens perceive their representatives as corrupt, they are conscious that they have the opportunity to "throw the rascals out" of the government in the next election. Therefore, in terms of government alternation, disproportional systems generate a greater sense of efficacy on the part of voters in making governments more accountable to them. 
Several authors emphasize that in the presence of lower levels of disproportionality and the consequent multiparty systems, voters may feel more satisfied because they have the opportunity to choose from a greater number of parties that are closest to their preferences (Lijphart, 1999; Powell, 2000). Nevertheless, while this political-institutional framework increases political representation, it weakens government responsibility (Kaiser et al., 2002). The broad government coalitions that are common in the presence of highly proportional systems do not often directly follow the outcome of the elections but are the results of political bargaining among parties. This context makes it easier for corrupt politicians to return to the government after the electoral round, making elections a blunt weapon. Italy’s "first republic" (1946-1994) represented an emblematic case in this sense. Consequently, voters feel that their representatives are less accountable and are likely to weight, more heavily, their corruption perceptions in forming their attitudes towards government.

Thus, our first research hypothesis is the following:

H1: With increasing levels of vote-seats disproportionality, the negative effects of perceived corruption on SWD weaken.

One might question the choice to focus our attention on electoral disproportionality because it is an outcome property of electoral systems that is mostly determined by the district magnitude and the threshold for representation, and also, associated with the adopted electoral formula. However, following the argument of Kaiser and colleagues (2002), we think that it is precisely the electoral disproportionality that, summarizing the effects played by several institutional arrangements, operationalizes the concept of the "possibility of alternation" at the 
government level that represents our core argument. However, to confirm that our argument is valid, we also test the conditioning role of district magnitude on the impact of perceived corruption on SWD. This choice allows us also to test the validity of an alternative argument advanced by the literature. According to the model proposed by Myerson (1993) and recalled by Persson, Tabellini and Trebbi (2003), a lower magnitude, in particular single-member districts, as well as higher thresholds impose stricter barriers on the election of new candidates in the electoral districts (barriers-toentry effect). Even if there are honest candidates that contest elections, a dishonest incumbent has a good chance of winning. Acting strategically, voters may decide to vote for a dishonest but ideologically preferred candidate because switching to the honest candidate risks giving the victory to a candidate distant from their policy preferences. This strategic dilemma should have negative consequences on the relation of accountability that links elected representatives to their voters. If voters perceive that they cannot hinder the re-election of a dishonest candidate, they will feel less attached to politics and less inclined to vote (Norris, 2004). Thus, voters' perceptions of corruption should have a higher negative impact on their democratic satisfaction.

If what we can call the "accountability effect" at the government level trumps the "barriers-to-entry effect" that operates at the district level, we should see H1 confirmed by our empirical analyses. If the contrary, our findings should instead provide evidence contrary to our expectation.

Electoral systems can mediate the impact of corruption on SWD through a second mechanism that stems from their ballot structure and mainly operates at the constituency level. This property refers to the nature of the vote choice and distinguishes electoral systems according to the relative strength of parties and citizens in shaping candidates' access to ballot and influencing their chances of being elected 
(Wallack et al., 2003). To vote for individual candidates, express a preferential vote or cast an ordinal vote, such as in STV, creates, at different degrees, a close link between the performance of the single incumbent and her reappointment. Candidate-oriented electoral systems, in which voters' choices play a crucial role in influencing candidates' electoral success, provide more incentives for candidates to cultivate their personal reputation, as opposed to party-centred systems, where the fate of the candidate is determined largely by their party support (Carey and Shugart, 1995; Wallack et al., 2003; Farrell and McAllister, 2006).

Thus, in a candidate-centred electoral system, the candidates' (re-)election ultimately rests on their capacity to attract votes (or preferences). Politicians may pursue this aim by maintaining an accountable and responsive behaviour but also by delivering benefits to appeal to voters. These benefits derive from legitimate legislative particularism and pork-barrel spending to clientelistic relations that can result in actual corrupt interactions and illegal vote buying (Carey and Shugart, 1995; Golden and Chang, 2001; Chang and Chu, 2006). ${ }^{4}$ Therefore, we could expect that voters in the presence of candidate-oriented electoral systems, though perceiving politicians as corrupt, may tolerate corruption in exchange for economic benefits and distributive policies focused on their district. Thus, perceived corruption should less affect their satisfaction with the way the democratic process works. ${ }^{5}$

However, legislative particularism benefits only targeted constituents and in particular those who voted for a candidate belonging to one of the government parties

\footnotetext{
${ }^{4}$ See also Della Porta and Vannucci (1995) on the link between preferential voting and connections between politicians and the mafia in southern Italy.

5 This mechanism may also explain the high re-election rate of corrupt politicians showed by countries, such as Italy and Japan (Manzetti and Wilson, 2007).
} 
and those who are closer to the interest groups that established some kind of clientelistic interaction with the winning candidates. Moreover, in candidate-oriented electoral systems, the incentives and the opportunities for voters and the electoral opponents to carefully monitor the candidates are higher than in the presence of closed party lists. As an increasingly large literature demonstrates, corruption has recently become a highly salient issue in worldwide electoral campaigns (Bågenholm, 2013; Bågenholm and Charron, 2014; Curini, 2015). Thus, when ballot control is mainly in the hands of the voters and a candidate is (supposed to be) involved in corruption scandals, his/her contenders are strongly incentivized to use corruption as a relevant issue in campaigning against her. Bågenholm and Charron (2014) have demonstrated that politicising corruption is a more effective strategy the lower the district magnitude, an aspect that is strongly correlated with voters' ballot control. In this kind of electoral system voters are more prone to react strongly against perceived corruption associated with a personal vote, irrespective of the particularistic benefits they can obtain. More precisely, hypothesis 2 is the following:

H2: With increasing voter control of the ballot, the negative effects of perceived corruption on SWD strengthen.

\section{Data and methods}

To test the hypotheses advanced above, we have used the CSES Module 2 dataset, which includes data on 40 elections held in 38 countries between 2001 and 2006. From this initial sample, we have excluded from the analysis the non-democratic regimes (Albania, 2005; Hong Kong, 2004; Kirghizstan, 2005; Russia, 2004) taking into consideration only those countries that in the year analysed were classified as "Free" 
according to the Freedom in the World Index released by Freedom House. ${ }^{6}$ Moreover, because of missing data on some explanatory variables, multilevel analyses employ data on 35 elections in 33 countries for a total of 29,376 observations. Portugal (2002 and 2005) and Taiwan (2001 and 2004) are counted twice.

Our dependent variable is the respondents' level of satisfaction with democracy (SWD). We reversed the original scale going from "very satisfied (1)" to "not at all satisfied (4)" so that higher values correspond to greater satisfaction with democracy.

Our main independent variable is the perceived level of corruption. We reversed the original coding, ranging from "very widespread (1)" to "it hardly happens at all (4)", so that higher values represent the citizens' perceptions that corruption is more widespread. As we have already mentioned, we believe that this survey item captures important variations in voters" perception of corruption at the "grand" level. Figure A1 in the Appendix plots the relationship between citizens' perceived corruption (averaged at the country-election level) and the Transparency International Corruption Perceptions Index (CPI). This graph lends additional credibility to our measure of corruption because it depicts a strong correlation $(\mathrm{r}=.90)$ with CPI, one of the most used measures of corruption in comparative studies.

To test the conditional hypotheses advanced in the previous section, we have made corruption interact with different features of the electoral system. To test H1, we have made corruption first interact with the level of vote-seats disproportionality as measured by Gallagher's (1991) least squares index. ${ }^{7}$ For the theoretical and

\footnotetext{
${ }^{6}$ See www.freedomhouse.org.

7 Data on the least-squares index of electoral disproportionality are taken from https://www.tcd.ie/Political_Science/staff/michael_gallagher/ElSystems/Docts/ElectionIndices.pdf.
}

Lijphart (1999) proposed calculating disproportionality in presidential and semi-presidential systems by 
methodological reasons explained above, we have also made corruption interact with the district magnitude. In the case of majoritarian and PR systems, the average district magnitude is obtained by dividing the number of assembly seats by the number of electoral districts, at the electoral tier at which votes are translated into seats. For proportional multi-tier systems and mixed systems, we first computed the magnitude of each tier by dividing the number of seats assigned at a given tier by the number of electoral districts at that tier. We then summed the resulting tier-level values, weighted by the proportion of tier-level seats over the assembly size. As we have no reason to expect that the mediating role of district magnitude is affected by the number of representatives in the parliament, we have normalised this measure by the assembly size (i.e., magnitude*100/assembly size). The resulting normalised values of district magnitude range from close to 0 to $100 .^{8}$

In $\mathrm{H} 2$, we have made corruption interact with the ballot score provided by Wallack and colleagues (2003). This variable measures the relative strength of parties and citizens in shaping candidates' access to the ballot and influencing their chances of

\footnotetext{
taking the geometric mean of the index obtained for presidential and for legislative elections. However, given that our theoretical argument is based on the relationship between voters and their representatives in the parliament, we considered it more appropriate to compute disproportionality looking only at legislative elections. As a robustness check, we have also tested H1 using a measure of disproportionality computed following the Lijphart (1999) method, and results are very similar.

${ }^{8}$ Data on the number of assembly seats and the number of electoral districts for each tier are gathered from Bormann and Golder (2013). As a further robustness check, we have also made corruption interact with the average district magnitude, weighted for the proportion of seats allocated in each tier as provided by the Database of Political Institutions, and results do not change.
} 
being elected (Wallack et al. 2003). ${ }^{9}$ It ranges from 0, indicating that parties exert strong control over the candidates' entry into politics, to 2 , for systems offering voters higher influence over the selection of candidates. PR closed lists are located at the bottom of this classification with a score equal or very close to 0 . It is followed by PR systems with flexible or open lists, mixed electoral systems, Single Transferable Vote (STV) and finally plurality and majority systems presenting the highest score (2). ${ }^{10}$ For multi-tier electoral systems, the variable is given by the average value of the ballot control scores assigned in each tier. Table A1 in the Appendix includes information and data on the main features of the electoral system adopted by each sample country outlined here.

\footnotetext{
${ }^{9}$ Ballot control is one component of a composite index obtained by averaging the ballot score with two other elements named Pool and Vote (see Carey and Shugart, 1995; Wallack et al., 2003). This index measures the propensity for a personal vote determined by different electoral systems. We prefer to use only the ballot component for two main reasons, one theoretical and one empirical. The former is that our theoretical argument relies precisely on the voters' versus parties' control of the ballot. The empirical reason is that the index of personal vote, aggregating different aspects of electoral institutions, is much more correlated with electoral disproportionality and district magnitude.

${ }^{10}$ The previous classification provided by Carey and Shugart (1995) departs from that of Wallack et al. (2003) used here because it assigns a ballot score of 0 instead of 2 to single-member districts. Farrell and McAllister (2006, 727-30) instead classify some PR-open lists (known as panachage) and STV as more candidate-centred systems than plurality and majority systems. However, considering the theoretical argument we have advanced concerning the role of ballot structure in mediating the effect of corruption on SWD. In this view, we agree with Wallack et al. (2003) that it is precisely in single-member plurality systems, in which the vote is a simple categorical choice between candidates, that the relationship that links representatives to their electorate is closer and stronger. Moreover, it is in single-member districts that voters tend to vote more strategically.
} 
The validity of our research hypotheses is established by controlling for the effect of a set of variables, both at the individual level and at the country level, which represent potential sources of spuriousness in the relation between corruption and SWD. ${ }^{11}$ At the individual level, we have included in the model four socio-demographic factors measuring age, gender, level of education and unemployment status of respondents. Moreover, we have included a categorical variable that relates to the respondents' political attitudes, namely, how much people think that politicians in power can make a difference. Higher values of this variable represent a stronger feeling towards the political efficacy of those who are in power. We should expect that people expressing this feeling are more satisfied with democracy. We have also included a dummy variable that takes into account the heterogeneity of voters, distinguishing between "winners" and "losers". This variable assumes value 1 for those respondents that in the last elections voted for one of the parties in the government, and 0 otherwise. ${ }^{12}$ A plethora of studies demonstrate that citizens who have voted for a government party tend to present higher levels of SWD (see Anderson and Guillory, 1997; Anderson and Tverdova, 2003; Curini et al., 2012; Singh, 2014). Furthermore, Dahlberg and Linde (2016) have recently shown that the impact of winner-loser status on SWD is affected by both the quality of the democratic process, influenced among other elements by the formal electoral institutions, and the quality of governance, which corruption strongly contributes to determining. Another variable measures the distance,

\footnotetext{
${ }^{11}$ Details on the coding of control variables and descriptive statistics of all the variables used in the analyses that follow are provided in the online Appendix.

${ }^{12}$ In presidential systems, voters are considered winners if they voted for the president's party or for one of the parties supporting the president in the Parliament. This is the same strategy adopted by other authors (Anderson and Tverdova, 2003; Curini et al., 2012).
} 
in absolute values, between the left-right self-reported position of the respondent and the position of the government. The latter is measured as the median point of the range of the government coalition, obtained by the absolute distance between the left-right positions of the two extreme parties. Finally, a dummy variable measures whether respondents feel close to any political party. Curini et al. (2012) confirm that people who are ideologically closer to the government and who feel close to a party express greater satisfaction. In general, ideology, partisanship and having voted for a government party may induce citizens to discount corruption in evaluating the functioning of democracy.

At the country level, we have controlled for the dispersion of different political parties around the position of the median voter on the left-right continuum, measured with the average party extremism formula developed by Ezrow and Xezonakis (2011). We have used the CSES respondents' left-right self-placement to estimate the median voter preferences in each country and the positions that surveyed citizens gave for different political parties to locate them on the left-right spectrum. As highlighted by Ezrow and Xezonakis (2011), we should expect that the higher the level of party extremism, the lower the SWD. We have also taken into account the difference between consolidated and newly established democracies by including in the right part of the regression models the age of democracy that measures the consecutive years from which a country is a democracy according to the Przeworski et al. (2000) classification. Newly established democracies systematically perform worse than consolidated democracies in terms of corruption control (Treisman, 2000). Moreover, in new democracies, citizens tend to be less attached to politics. Dahlberg et al. (2015) show that the level of institutional consolidation affects how the input-side and the outputside of democracy affect democratic satisfaction. Moreover, we have also controlled for 
CPI that provides a system-level measure of corruption. This variable might affect the respondents' perceptions that we use as the main predictor and allows us to control for the quality of governance. Finally, we have also considered the economic performances of the different countries. As showed by Bellucci and Memoli (2012), the better the economic performance of a political system, the higher the SWD. We have considered two different variables: the natural logarithm of the GDP per capita, measured in the year before the elections, and the average growth in GDP in the five years before the elections. Data are gathered from the World Development Indicators collected by the World Bank. ${ }^{13}$

Considering that our dependent variable - SWD - is a four-point ordinal measure, we have applied an ordered regression model (see Long, 1997). Moreover, our dataset combines information from the individual level of respondents with information from the aggregate level of the 35 country-election years analysed. To appropriately model the hierarchical structure of the data, we decided to use a multilevel ordered logistic model (see Rabe-Hesket and Skrondal, 2012). Ignoring the hierarchical character of data generates incorrect standard errors and increases the risk of incurring a Type I error (see Steenbergen and Bradford, 2002). In any ordinal regression model, the dependent variable is regarded as a latent variable that is estimated as a linear function of the independent variables and a set of thresholds defined as cut of points. The probability of observing a given outcome, therefore, corresponds to the probability that the estimated linear function is within the range of the cut points estimated for the outcome.

We have run an a-theoretical model that does not include individual-level or aggregate-level predictors. This model allows us to decompose the total variance in our

\footnotetext{
${ }^{13}$ See http://data.worldbank.org/data-catalog/world-development-indicators.
} 
dependent variable between the two levels in which our data are organized and compute the intra-class correlation $\rho$, which indicates the total variation in the level of SWD that can be explained by country-level differences only. The value of $\rho$ obtained by the null model is approximately 20 percent and significant at $\mathrm{p}<.01$. This estimation lends strong support to the choice of applying a multilevel model to our data. For the purpose of our paper, random slopes for corruption are estimated, allowing different effects of perceived corruption on SWD in different countries. The cross-level interactions aim at explaining these variations by mediating macro factors, which refer to features of the electoral system, adopted in each sample country. ${ }^{14}$

\section{Empirical results}

Table 1 reports the results of five multilevel regression models that test the validity of the two conditional hypotheses advanced above. We have made perceived corruption interact with electoral disproportionality (Model 1), district magnitude (Model 2) and ballot control (Model 3). Model 4 includes both the interaction terms corruption*disproportionality and corruption*ballot control, while Model 5 includes both corruption*district magnitude and corruption*ballot control. All these models also present the control variables previously described among the regressors.

\footnotetext{
${ }^{14}$ Given the low number of upper level units (35), the low variance in the slope of our independent variable - corruption - and the fact that the cross-level interactions tested account for almost all of the variance in the slope of corruption, we have re-run our analyses adopting a random intercept model instead of random slopes. Results obtained are very similar to the main findings presented in the article and are available upon request.
} 
Table 1 around here

Given the conditional nature of our research hypotheses, the interaction terms play a crucial role in determining whether our results confirm their validity (Brambor et al., 2006; Berry et al., 2012). Coefficients of the interactions terms are in the expected direction and in almost all the cases statistically significant. However, in non-linear models it is not possible to get substantively meaningful results simply looking at the sign and the significance of the interaction term. In (ordinal) logistic models, the effect of an independent variable on the dependent variable depends on the values assumed by all the other predictors included in the model (Ai and Norton 2003; Berry et al. 2010). To correctly evaluate the statistical and substantial significance as well as the direction of the relationship between perceived corruption and SWD, we need to plot the graph of the marginal effect of corruption on SWD at changing levels of the mediating macrolevel factors (Berry et al., 2010; 2012). Figure 2 plots the marginal effects of corruption on the probability that a respondent is fairly or very satisfied with democracy (SWD>2), as the disproportionality level changes and while holding other independent variables at their mean. The solid black line identifies the marginal effect of passing from the lowest category of corruption equal to 1 (it hardly happens at all) to the highest value of corruption equal to 4 (very widespread), while the two dashed lines represent the lower and upper bounds of the $95 \%$ confidence interval. The graph reported in Figure 2 clearly shows that for increasing levels of disproportionality, the negative effect of perceived corruption on democratic satisfaction weakens. This finding confirms H1, indicating that in countries using a highly disproportional electoral system, voters disregard their perceptions of corruption in forming their attitudes towards the democratic process. Although citizens know that politicians are corrupt, they also know 
that they can punish them in the next elections because of the presence of an electoral system that increases the possibility of government alternation.

Figure 2 about here

As explained above, to confirm the argument advanced by H1, in Model 2 and Model 5 we have also made corruption interact with district magnitude. Figure 3, plotting the marginal effect of corruption (understood as the discrete change of passing from corruption $=1$ to corruption $=4$ ) on the probability that SWD>2, confirms H1. With increasing levels of district magnitude, the marginal effect of perceived corruption on SWD strengthens. Corruption negatively affects citizens' democratic satisfaction more in proportional systems with large districts than in low-magnitude electoral systems with more disproportional outcomes. According to the results shown in Figures 2 and 3, the "accountability effect" determined by highly disproportional systems that increase the possibility of government alternation trumps the "barriers-to-entry effect" that works in single-member districts.

Figure 3 about here

In contrast, $\mathrm{H} 2$ postulates that the negative effect of perceived corruption on SWD becomes stronger in the presence of a higher score on the ballot control index. Computing the marginal effect of corruption on SWD, we detect that it becomes substantially more negative with increasing values of ballot control (Figure 4). Casting a ballot for an individual candidate or expressing a preferential vote strengthens the negative effect of perceived corruption on citizens' satisfaction with democracy. This 
finding supports $\mathrm{H} 2$. By virtue of the close relationship that representatives establish with their electorate in candidate-centred electoral systems, voters tend to react to corruption more strongly than in party-centred systems, irrespective of the potential benefits and legislative particularism that can follow corruption.

Figure 4 about here

Our main results are robust to alternative estimation techniques. We first collapsed the four original categories of SWD, creating a binary dependent variable, though we were aware that this choice would mean forfeiting useful information. ${ }^{15}$ Second, considering that there is no agreement in the literature about the minimum number of upper-level units that justifies the adoption of multilevel modelling, we have re-estimated our models through a pooled ordinal logistic model including a dummy variable for each country-election present in the sample (see Arceneaux and Nickerson 2009) and robust standard errors. Finally, considering the popular legitimation of both presidents and parliaments due to the separation of powers in presidential systems, we have tested our models only on parliamentary systems. Even when dichotomizing SWD, abandoning multilevel modelling and excluding presidential systems, the results obtained are very similar to the main ones. High levels of electoral disproportionality and low levels of district magnitude weaken the negative impact of perceived corruption on satisfaction, whereas voters' ballot control has a reinforcing effect.

\footnotetext{
${ }^{15}$ The categories "not at all satisfied" and "not very satisfied" are collapsed into the category "not satisfied" (0), while the categories "fairly satisfied" and "very satisfied" are collapsed into the category "satisfied" (1).
} 
In conclusion, most of the control variables tested are also significantly related with the dependent variable. At the individual level, age and unemployment status are negatively associated with SWD, indicating that older people and the unemployed are less satisfied with democracy. In contrast, people who think that politicians in power can make a difference, citizens who had voted for one of the government parties, and people who report feeling close to a political party express higher levels of SWD. The regression coefficient of the distance between the ideological preferences of the citizens and the government, though displaying the predicted negative sign, is instead not significantly related to SWD. The dispersion of political parties on the left-right continuum is significantly associated with SWD only in two out of five models, but with a direction contrary to previous empirical evidence.

Among the country-level controls, long-lasting democracies tend to present higher levels of SWD, while citizens who live in countries with higher CPI scores tend to be less satisfied. This result indicates that, even controlling for corruption at the systemic level, citizens' perceptions of corruption are negatively and significantly associated with their satisfaction with the functioning of democracy. Regarding the two macroeconomic variables, both the average growth of real GDP in the five years before the elections and per capita income positively affect SWD.

\section{Concluding remarks}

It has been demonstrated that corruption is detrimental to SWD and institutional confidence. While existing literature has investigated how electoral systems can help to constrain corruption, we still have little knowledge about the role played by institutions in enhancing political support. In contrast to most of the previous studies, which analysed the direct effects of electoral systems on political support and produced 
inconclusive results, this research investigates their role in mediating the negative impact of corruption on SWD. We have focused on two specific aspects of the electoral systems - vote-seat disproportionality and the ballot structure - postulating alternative hypotheses on their role in weakening or strengthening the negative effects of perceived corruption on SWD.

The validity of the research hypotheses that were advanced has been tested through the CSES Module 2 dataset, which includes data on 35 elections in 33 consolidated and newly established democracies. The findings confirm that high levels of electoral disproportionality weaken the negative effect of perceived corruption on democratic satisfaction. At the same time, the empirical analysis provides evidence in support of a reinforcing effect of the voters' control of the ballot on the impact of corruption on democratic satisfaction.

The most important conclusion that we can draw from our findings is that institutions matter in affecting citizens' attitudes towards the democratic process. The existing literature and our study identified several factors that affect citizens' democratic satisfaction. Among them, the role of politicians, the policy preferences of parties and governments, the national and personal economic situation and citizens' voting preferences and choices are strong predictors of democratic satisfaction. A relevant role is also played by the features of the country in which citizens live, such as the duration and quality of the democratic institutions, the level of economic development, and the spread of corruption. Compared to these factors, electoral institutions display weaker (if not trivial) direct effects on SWD. However, our empirical findings demonstrate that institutions have significant conditional effects in moderating the impact of corruption - one of the most detrimental factors of political support - on satisfaction with democracy. 
However, at the same time, our findings confirm once again the complex consequences of electoral systems. The present study demonstrates that different aspects that together determine electoral systems controversially affect the relationship between perceived corruption and citizens' democratic satisfaction. Two divergent mechanisms are simultaneously in action. One mechanism operates at the government level, where a higher degree of disproportionality increases the possibility of government alternation. Voters who perceive politicians as corrupt know that they can easily punish them with their vote, and this weakens corruption's negative effect on their democratic satisfaction. Another mechanism considers the relationship between the candidates and their constituents at the district level. Considering the close link established between candidates and their constituents in candidate-oriented electoral systems, corruption becomes a salient issue in evaluating candidates' performance. Irrespectively of the potential benefits they can obtain from pork-barrel spending, legislative particularism and clientelism, if voters perceive widespread corruption, they will react more strongly against it, reinforcing the impact of their perceptions on their degree of satisfaction with the way democracy works.

Undoubtedly, our knowledge about the role of the electoral systems in mediating the negative impact of corruption on SWD is far from definitive. In our opinion, further research should analyse both theoretically and empirically if and under which political, social and economic conditions one of these two mechanisms might provide a stronger moderating effect on citizens' perceived corruption than the other. Future studies in this direction would help to understand the net conditioning effect played by electoral institutions on the relationship between corruption and political support. Only by doing this can we deduce more clearly the policy implications regarding which institutional 
framework is more suitable concerning reducing the detrimental consequences of corruption and increasing citizens' democratic satisfaction.

In conclusion, we suggest three other main issues on which future studies should focus. First, it would be helpful to investigate the potentially different effects played by several forms of preferential voting by developing research analyses that focus exclusively on PR systems. At the same time, more attention should be devoted to mixed electoral systems that are based on single member districts and one or more larger districts. Second, even though scholars face non-trivial problems of data availability, the collection of cross-national panel data would provide useful material for future research. For instance, analysing a longer time span would allow scholars to investigate how the effects of perceived corruption on satisfaction with democracy change before and after electoral reforms adopted by countries such as Italy, Japan and New Zealand. These reforms, in fact, strongly modified several crucial aspects of the arguments set out in this paper, such as the average district magnitude, vote-seat disproportionality and ballot structure. Finally, while it is clearly demonstrated that political corruption is negatively associated with the short-term, specific form of support as it has been addressed in this study, further research could investigate the relationship between corruption and diffuse support. This research question assumes particular relevance in newly established democracies where citizens' confidence in democracy as a form of government is generally lower than in consolidated democratic systems. In these contexts, unconsolidated party systems and unstable institutions favour corruption and the discretionary power of public officials. 


\section{References}

Aarts, K. and J. Thomassen (2008), 'Satisfaction with Democracy: Do institutions matter?', Electoral Studies 27(1): 5-18.

Ai, C. and E.C. Norton (2003), 'Interaction Terms in Logit and Probit Models', Economics Letters 80: 123-129

Anderson, C.J. and C.A. Guillory (1997), 'Political Institutions and Satisfaction with Democracy: A Cross-National Analysis of Consensus and Majoritarian Systems', American Political Science Review 91(1): 66-81.

Anderson, C.J. and Y.V. Tverdova (2003), 'Corruption, Political Allegiances and Attitudes toward Government in Contemporary Democracies', American Journal of Political Science 47(1): 91-109.

Arceneaux, K. and D.W. Nickerson (2009), 'Modelling Certainty with Clustered Data: A Comparison of Methods', Political Analysis 17(2): 177-90.

Bågenholm, A. (2013), 'Throwing the rascals out? The electoral effects of corruption allegations and corruption scandals in Europe 1981-2011', Crime, Law \& Social Change 60: 595-609.

Bågenholm, A. and N. Charron (2014), 'Do Politics in Europe Benefit from Politicising Corruption?', West European Politics 37(5): 903-31.

Bellucci, P. and V. Memoli (2012), 'The determinans of support in Europe', in D. Sanders, P.C. Magalhaes and G. Toka (eds), Citizens and European Polity. Mass Attitudes Toward European and National Polities, Oxford: Oxford University Press, pp. 9-38.

Bernauer, J. and A. Vatter (2012), 'Can't Get No Satisfaction with the Westminster Model? Winners, Losers and the Effects of Consensual and Direct Democratic 
Institutions on Satisfaction with Democracy', European Journal of Political Research 51(4): 435-68.

Berry, W.D., J.H.R. DeMeritt and J. Esarey (2010), 'Testing for Interaction in Binary Logit and Probit Models: Is a Product Term Essential?', American Journal of Political Science 54(1): 248-266.

Berry, W.D., M. Golder and D. Milton (2012), 'Improving Tests of Theories Positing Interaction', The Journal of Politics 74(3): 653-71.

Bormann, N.C. and M. Golder (2013), 'Democratic Electoral Systems around the World, 1946-2011', Electoral Studies 32(2): 360-69.

Brambor, T., W.R. Clark and M. Golder (2006), 'Understanding Interaction Models: Improving Empirical Analyses', Political Analysis 14(1): 63-82.

Carey, J.M. and M.S. Shugart (1995), 'Incentives to Cultivate a Personal Vote: A Rank Ordering of Electoral Formulas', Electoral Studies 14(4): 417-39.

Chang, E.C. and Y.-h. Chu (2006), 'Corruption and Trust: Exceptionalism in Asian Democracies?', The Journal of Politics 68(2): 259-71.

Charron, N. (2015), 'Do Corruption Measures Have a Perception Problem? Assessing the Relationship Between Experiences and Perceptions of Corruption Among Citizens and Experts', European Political Science Review 8(1): 147-171.

Clausen, B., K. Aart and N. Zsolt (2011), 'Corruption and Confidence in Public Institutions: Evidence from a Global Survey', The World Bank Economic Review 25(2): 212-49.

Curini, L. (2015), 'The Conditional Ideological Inducement to Campaign on Character Valence Issues in Multiparty Systems: The Case of Corruption', Comparative Political Studies 48(2): 168-92. 
Curini, L., W. Jou and V. Memoli (2012), 'Satisfaction with Democracy and the Winner/Loser Debate: The Role of Policy Preferences and Past Experience', British Journal of Political Science 42(2): 241-61.

Dahlberg, S. and S. Holmberg (2014), 'Democracy and Bureaucracy: How their Quality Matters for Popular Satisfaction', West European Politics 37(3): 515-537.

Dahlberg, S., J. Linde and S. Holmberg (2015), 'Democratic Discontent in Old and New Democracies: Assessing the Importance of Democratic Input and Governmental Output', Political Studies 63(1): 18-37.

Dahlberg, S. and J. Linde (2016), 'Losing Happily? The Mitigating Effect of Democracy and the Quality of Government on the Winner-Loser Gap in Political Support', International Journal of Public Administration 39(9): 652-664.

Della Porta, D. (2000), 'Social Capital, Beliefs in Government, and Political Corruption', in S. Pharr and R. Putnam (eds), Disaffected Democracies: What's Troubling the Trilateral Countries, Princeton: Princeton University Press, pp. 202-230.

Della Porta, D. and A. Vannucci (1995), 'Politics, the Mafia, and the Market for Corrupt Exchange', in C. Mershon and G. Pasquino (eds.), Italian Politics: Ending the First Republic, Boulder: Westview Press.

Easton, D. (1965), A Framework for Political Analysis. Englewood Cliffs: Prentice Hall.

Easton, D. (1975), 'A Re-assessment of the Concept of Political Support', British Journal of Political Science 5(4): 435-57.

Ezrow, L. and G. Xezonakis (2011) 'Citizen Satisfaction with Democracy and Parties' Policy Offerings', Comparative Political Studies 44(9): 1152-1178. 
Farrell, D.M. (2001), Electoral Systems. A Comparative Introduction. London: Macmillan Palgrave.

Farrell, D.M. and I. McAllister (2006), 'Voter Satisfaction and Electoral Systems: Does Preferential Voting in Candidate-Centred Systems Make Difference?', European Journal of Political Research 45(5): 723-49.

Gallagher, M. (1991), 'Proportionality, Disproportionality and Electoral Systems', Electoral Studies 10(1): 33-51.

Golden, M. and E.C.C. Chang (2001), 'Competitive Corruption: Factional Conflict and Political Malfeasance in Postwar ItalianChristian Democracy', World Politics 53(4): 588-622.

Kaiser, A., M. Lenhert, B. Miller and U. Sieberer (2002), 'The Democratic Quality of Institutional Regimes: A Conceptual Framework', Political Studies 50(2): 31331.

Karp, J.A., and S. Bowler (2001), 'Coalition Government and Satisfaction with Democracy: An Analysis of New Zealand's Reaction to Proportional Representation', European Journal of Political Research 40(1): 57-79.

Klingemann, H.-D. (1999), 'Mapping Political Support in the 1990s: A Global Analysis', in P. Norris (ed.), Critical Citizens. Global Support for Democratic Governance, Oxford, New York: Oxford University Press, pp. 31-56.

Lijphart, A. (1994), Electoral Systems and Party Systems: A Study of Twenty-Seven Democracies 1945-1990, Oxford, New York: Oxford University Press.

Lijphart, A. (1999), Patterns of Democracy: Government Forms and Performance in Thirty-Six Countries. New Haven: Yale University Press. 
Linde, J. and J. Ekman (2003), 'Satisfaction with democracy: A note on a frequently used indicator in comparative politics', European Journal of Political Research 42(3): 391-408.

Long, S.J. (1997), Regression Models for Categorical and Limited Dependent Variables, Thousand Oaks: Sage.

Lupia, A. (2003), 'Delegation and Its Perils', in K. Strøm, W.C. Müller and T. Bergman (eds.), Delegation and Accountability in Parliamentary Democracies, Oxford, New York: Oxford University Press, pp. 33-54.

Manzetti, L. and C.J. Wilson (2007), 'Why Do Corrupt Governments Maintain Public Support?', Comparative Political Studies 40(8): 949-70.

Melgar, N., M. Rossi and T. Smith (2010), 'The Perception of Corruption', International Journal of Public Opinion Research 22(1): 120-131.

Mishler, W. and R. Rose (2001), 'What Are the Origins of Political Trust? Testing Institutional and Cultural theories in Post-Communist Societies', Comparative Political Studies 34(1): 30-62.

Mishler, W. and R. Rose (2008), 'Seeing is not Always Believing: Measuring Corruption Perceptions and Experiences. University of Manchester', UK: unpublished paper. Myerson, R.B. (1993), 'Effectiveness of Electoral Systems for Reducing Government Corruption: A Game-Theoretic Analysis', Games and Economic Behaviour 5: $118-132$.

Norris, P. (ed.) (1999a), Critical Citizens. Global Support for Democratic Governance, Oxford: Oxford University Press.

Norris, P. (1999b), 'Institutional Explanations for Political Support', in P. Norris (ed.), Critical Citizens. Global Support for Democratic Governance, Oxford: Oxford University Press, pp. 217-35. 
Norris, P. (2004), Electoral Engineering: Voting Rules and Political Behaviour. New York: Cambridge University Press.

Pellegata, A. and V. Memoli (2016), 'Can Corruption Erode Confidence in Political Institutions Among European Countries? Comparing the Effects of Different Measures of Perceived Corruption', Social Indicators Research 37(1): 51-65.

Persson, T., G. Tabellini and F. Trebbi (2003), 'Electoral Rules and Corruption', Journal of the European Economic Association 1(4): 958-89.

Powell, B. G. (2000), Elections as Instruments of Democracy. Majoritarian and Proportional Visions, New Haven: Yale University Press.

Przeworski, A., M.E. Alvarez, J.A. Cheibub and F. Limongi (2000), Democracy and Development. Political Institutions and Well-Being in the World 1950-1990, Cambridge, UK: Cambridge University Press.

Rabe-Hesket, S. and A. Skrondal (2012), Multilevel and Longitudinal Modeling Using Stata. Categorical Responses, Counts and Survival, College Station: Stata Press Publication.

Rae, D.W. (1967), The Political Consequences of the Electoral Laws, New Haven: Yale University Press.

Rose-Ackerman, S. (1999), Corruption and Government. Causes, Consequences and Reform, Cambridge: Cambridge University Press.

Rothstein, B. and J. Teorell (2008), 'What Is Quality of Government? A Theory of Impartial Government Institutions', Governance 21(2): 165-190.

Sarsfield, R. and F. Echegaray (2005), 'Opening the Black Box: How Satisfaction with Democracy and its Perceived Efficacy Affect Regime Preference in Latin America', International Journal of Public Opinion Research 18(29): 153-73. 
Seligson, M.A. (2002), 'The Impact of Corruption on Regime Legitimacy: A Comparative Study of Four Latin American Countries', Journal of Politics 64(2): 408-33.

Singh, S.P. (2014), 'Not All Elections Winners Are Equal: Satisfaction with Democracy and the Nature of the Vote', European Journal of Political Research 53(2): 30827.

Steenbergen, M.R. and J.S. Bradford (2002), 'Modelling Multilevel Data Structure', American Journal of Political Science 46(1): 218-37.

Tavits, M. (2007), 'Clarity of Responsibility and Corruption', American Journal of Political Science 51(1): 218-29.

Treisman, D. (2000), 'The Causes of Corruption: A Cross-national Study', Journal of Public Economics 76(3): 399-457.

Treisman, D. (2007), 'What Have We Learned About the Causes of Corruption from Ten Years of Cross-National Empirical Research?', Annual Review of Political Science 10: 211-44.

Xezonakis, G., S. Kosmidis and S. Dahlberg (2016), 'Can Electors Combat Corruption? Institutional Arrangements and Citizen Behavior', European Journal of Political Research 55(1): 160-176.

Wagner, A.F., F.G. Schneider and M. Halla (2009), 'The quality of institutions and satisfaction with democracy in Western Europe - a panel analysis'. European Journal of Political Economy 25(1): 30-41.

Wallack, J.S., A. Gaviria, U. Panizza and E. Stein (2003), 'Particularism around the World', The World Bank Economic Review 17(1): 133-43.

Warwick, P.V. (1994), Government Survival in Parliamentary Democracies, Cambridge: Cambridge University Press. 
Warwick, P.V. (2011), 'Government Intentions and Citizens Preferences in a Dynamic Perspective', British Journal of Political Science 41(3): 599-619. 
Table 1. Main results of multilevel ordered logit on satisfaction with democracy (SWD)

\begin{tabular}{|c|c|c|c|c|c|}
\hline & Model 1 & Model 2 & Model 3 & Model 4 & Model 5 \\
\hline \multirow[t]{2}{*}{ Corruption } & -0.598 & -0.509 & -0.525 & -0.574 & -0.419 \\
\hline & $(0.031)^{* * *}$ & $(0.020)^{* * *}$ & $(0.031)^{* * *}$ & $(0.032) * * *$ & $(0.028)^{* * *}$ \\
\hline \multirow[t]{2}{*}{ Disproportionality } & -0.020 & & & -0.049 & \\
\hline & $(0.013)$ & & & $(0.016) * * *$ & \\
\hline \multirow{2}{*}{ Corruption*Disproportionality } & 0.008 & & & 0.012 & \\
\hline & $(0.004)^{*}$ & & & $(0.005)^{* *}$ & \\
\hline \multirow[t]{2}{*}{ District Magnitude } & & -0.000 & & & 0.004 \\
\hline & & $(0.002)$ & & & $(0.003)^{*}$ \\
\hline \multirow[t]{2}{*}{ Corruption*District Magnitude } & & -0.002 & & & -0.003 \\
\hline & & $(0.001)^{* * *}$ & & & $(0.001)^{* * *}$ \\
\hline \multirow[t]{2}{*}{ Ballot Control } & & & 0.376 & 0.490 & 0.425 \\
\hline & & & $(0.095)^{* * *}$ & $(0.104)^{* * *}$ & $(0.079)^{* * *}$ \\
\hline \multirow[t]{2}{*}{ Corruption*Ballot Control } & & & -0.027 & -0.053 & -0.089 \\
\hline & & & $(0.030)$ & $(0.030)^{*}$ & $(0.024)^{* * *}$ \\
\hline \multirow[t]{2}{*}{ Age } & -0.025 & -0.025 & -0.025 & -0.025 & -0.025 \\
\hline & $(0.009)^{* * *}$ & $(0.009)^{* * *}$ & $(0.009)^{* * * *}$ & $(0.007)^{* * *}$ & $(0.007)^{* * *}$ \\
\hline \multirow[t]{2}{*}{ Gender } & -0.031 & -0.031 & -0.031 & -0.030 & -0.031 \\
\hline & $(0.025)$ & $(0.023)$ & $(0.024)$ & $(0.024)$ & $(0.023)$ \\
\hline \multirow[t]{2}{*}{ Education } & 0.020 & 0.021 & 0.020 & 0.020 & 0.020 \\
\hline & $(0.016)$ & $(0.016)$ & $(0.018)$ & $(0.018)$ & $(0.016)$ \\
\hline \multirow[t]{2}{*}{ Unemployed } & -0.233 & -0.231 & -0.233 & -0.233 & -0.232 \\
\hline & $(0.057)^{* * *}$ & $(0.050)^{* * *}$ & $(0.053)^{* * *}$ & $(0.056)^{* * *}$ & $(0.054)^{* * *}$ \\
\hline \multirow[t]{2}{*}{ Politicians make difference } & 0.103 & 0.104 & 0.103 & 0.103 & 0.103 \\
\hline & $(0.009)^{* * *}$ & $(0.010)^{* * *}$ & $(0.010)^{* * *}$ & $(0.011)^{* * *}$ & $(0.011)^{* * *}$ \\
\hline \multirow[t]{2}{*}{ Winner } & 0.382 & 0.382 & 0.382 & 0.382 & 0.382 \\
\hline & $(0.024) * * *$ & $(0.023)^{* * *}$ & $(0.025)^{* * *}$ & $(0.024)^{* * * *}$ & $(0.024)^{* * *}$ \\
\hline \multirow[t]{2}{*}{ Closeness to party } & 0.223 & 0.222 & 0.223 & 0.223 & 0.222 \\
\hline & $(0.026)^{* * *}$ & $(0.022)^{* * *}$ & $(0.027)^{* * *}$ & $(0.022) * * *$ & $(0.024)^{* * *}$ \\
\hline \multirow[t]{2}{*}{ Distance from Government } & -0.006 & -0.006 & -0.006 & -0.006 & -0.006 \\
\hline & $(0.007)$ & $(0.008)$ & $(0.008)$ & $(0.009)$ & $(0.009)$ \\
\hline \multirow[t]{2}{*}{ Average Party Extremism } & 0.004 & 0.037 & 0.072 & 0.081 & 0.063 \\
\hline & $(0.026)$ & $(0.023)$ & $(0.026)^{* * *}$ & $(0.026)^{* * *}$ & $(0.024)^{* * *}$ \\
\hline \multirow[t]{2}{*}{ Age of Democracy } & 0.004 & 0.005 & 0.002 & 0.002 & 0.004 \\
\hline & $(0.001)^{* * *}$ & $(0.001)^{* * *}$ & $(0.001)^{* * *}$ & $(0.001)^{* * *}$ & $(0.001)^{* * *}$ \\
\hline \multirow[t]{2}{*}{ CPI } & -0.063 & -0.033 & -0.056 & -0.038 & -0.039 \\
\hline & $(0.014)^{* * *}$ & $(0.015)^{* *}$ & $(0.013)^{* * *}$ & $(0.014)^{* * *}$ & $(0.014)^{* * *}$ \\
\hline (log) GDP per capita & 0.227 & 0.196 & 0.346 & 0.384 & 0.260 \\
\hline & $(0.042)^{* * *}$ & $(0.041)^{* * *}$ & $(0.048)^{* * *}$ & $(0.051)^{* * *}$ & $(0.057)^{* * *}$ \\
\hline GDP Growth & 0.056 & 0.036 & 0.058 & 0.063 & 0.042 \\
\hline & $(0.007)^{* * *}$ & $(0.007)^{* * *}$ & $(0.007)^{* * *}$ & $(0.008)^{* * *}$ & $(0.008)^{* * *}$ \\
\hline Cut point 1 & -1.246 & -1.273 & 0.396 & 0.683 & -0.242 \\
\hline & $(0.419)^{* * * *}$ & $(0.437)^{* * *}$ & $(0.508)$ & $(0.554)$ & $(0.612)$ \\
\hline Cut point 2 & 0.846 & 0.819 & 2.487 & 2.774 & 1.850 \\
\hline & $(0.420)^{* * *}$ & $(0.437)^{*}$ & $(0.508)^{* * *}$ & $(0.555)^{* * *}$ & $(0.610)^{* * *}$ \\
\hline Cut point 3 & 4.032 & 4.005 & 5.674 & 5.961 & 5.036 \\
\hline & $(0.425)^{* * *}$ & $(0.440)^{* * *}$ & $(0.513)^{* * *}$ & $(0.559)^{* * *}$ & $(0.610)^{* * *}$ \\
\hline Var. (Corruption) & 0.044 & 0.040 & 0.044 & 0.042 & 0.036 \\
\hline & $(0.009)^{* * *}$ & $(0.010)^{* * * *}$ & $(0.010)^{* * *}$ & $(0.009)^{* * *}$ & $(0.009)^{* * *}$ \\
\hline Var. (Country-election) & 0.552 & 0.562 & 0.488 & 0.447 & 0.480 \\
\hline & $(0.120)^{* * *}$ & $(0.131)^{* * *}$ & $(0.109)^{* * *}$ & $(0.103)^{* * *}$ & $(0.109)^{* * *}$ \\
\hline Cov. (country intercept / Corruption & -0.128 & -0.131 & -0.123 & -0.113 & -0.113 \\
\hline & $(0.031)^{* * * *}$ & $(0.036)^{* * *}$ & $(0.031)^{* * * *}$ & $(0.029) * * *$ & $(0.030)^{* * * *}$ \\
\hline AIC & 60907.68 & 60894.79 & 60900.97 & 60902.6 & 60894.91 \\
\hline $\mathrm{N}$ & 29,376 & 29,376 & 29,376 & 29,376 & 29,376 \\
\hline Groups & 35 & 35 & 35 & 35 & 35 \\
\hline
\end{tabular}

Note: Standard errors in parentheses. Significance: * $p<0.1 ; * * p<0.05 ; * * * p<0.01$. 


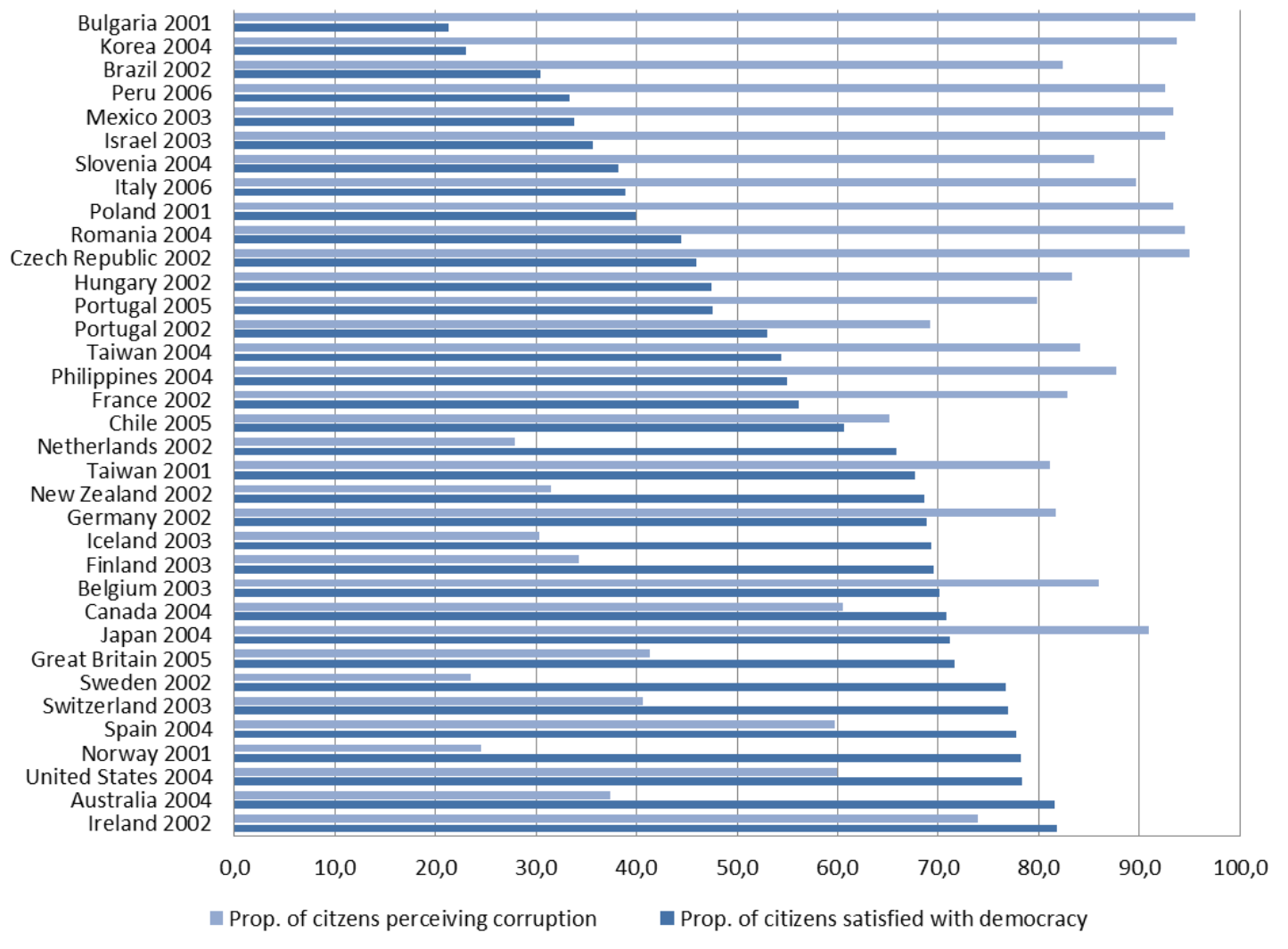

Figure 1 Proportion of respondents fairly or very satisfied with democracy and of respondents who perceive a quite or very widespread corruption in each country/year. 


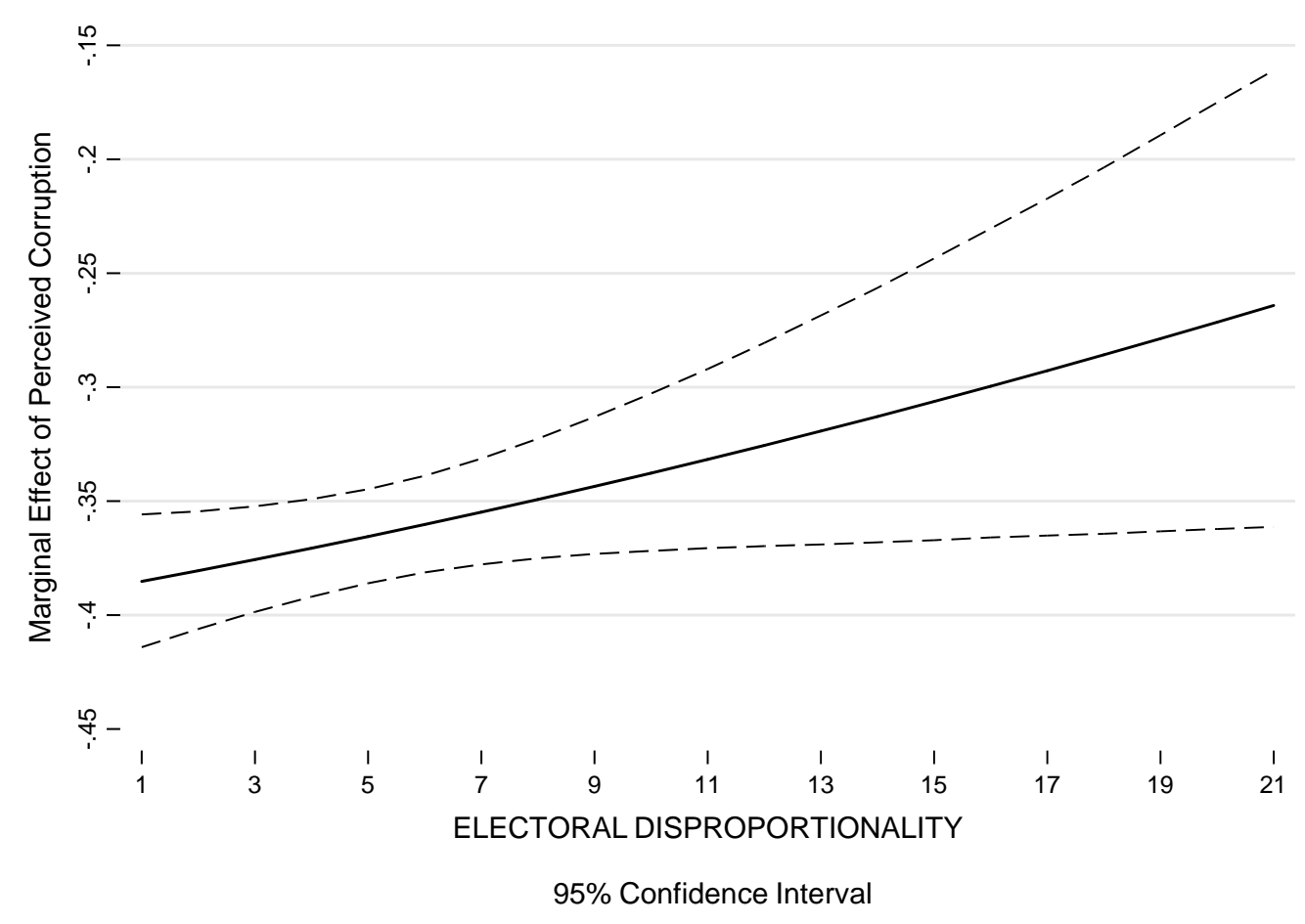

Figure 2 Marginal effect of corruption on satisfaction with democracy, as vote-seat disproportionality increases.

Note: Dependent variable is the probability of being fairly or very satisfied with democracy 


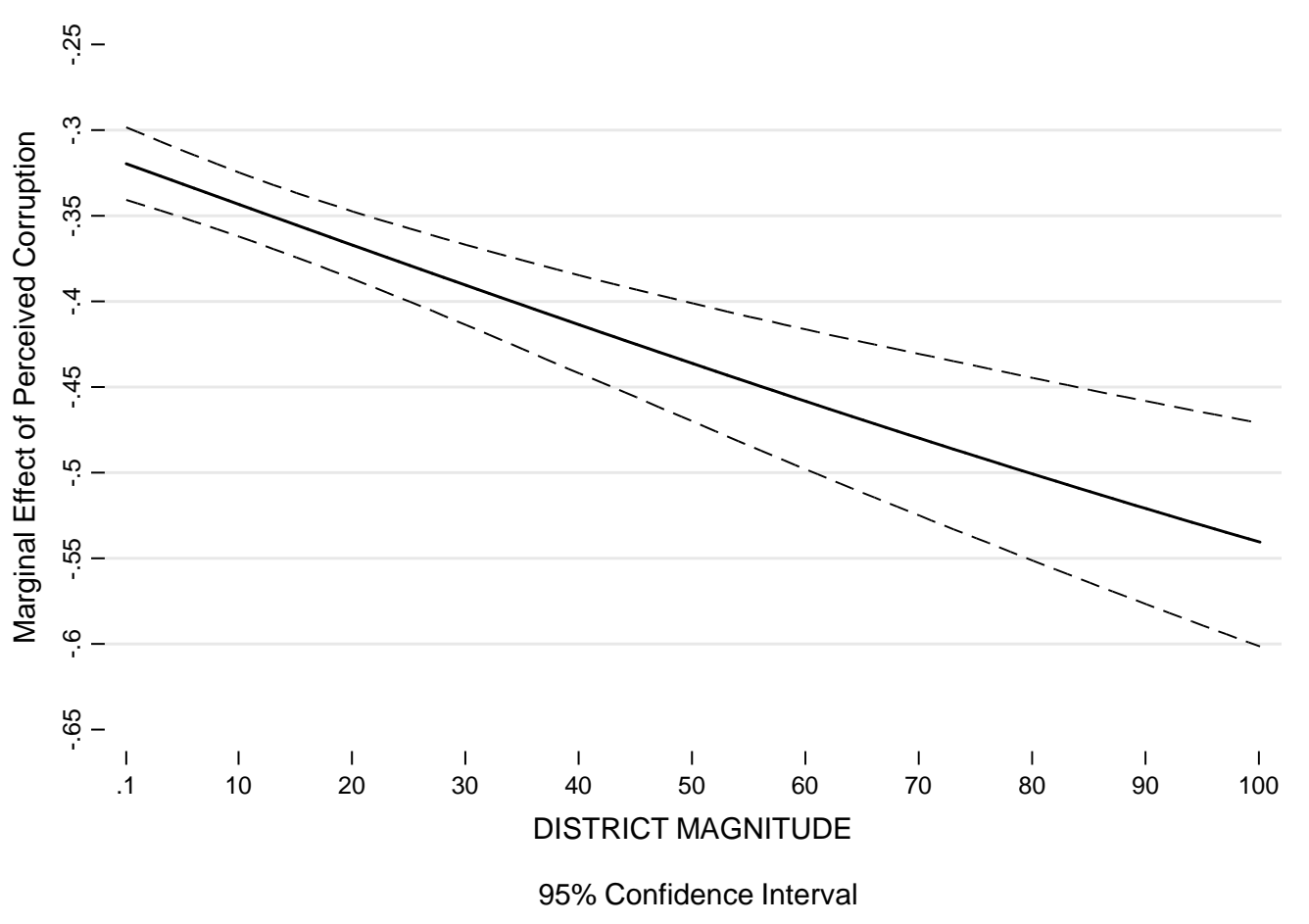

Figure 3 Marginal effect of corruption on satisfaction with democracy, as the district magnitude increases.

Note: Dependent variable is the probability of being fairly or very satisfied with democracy 


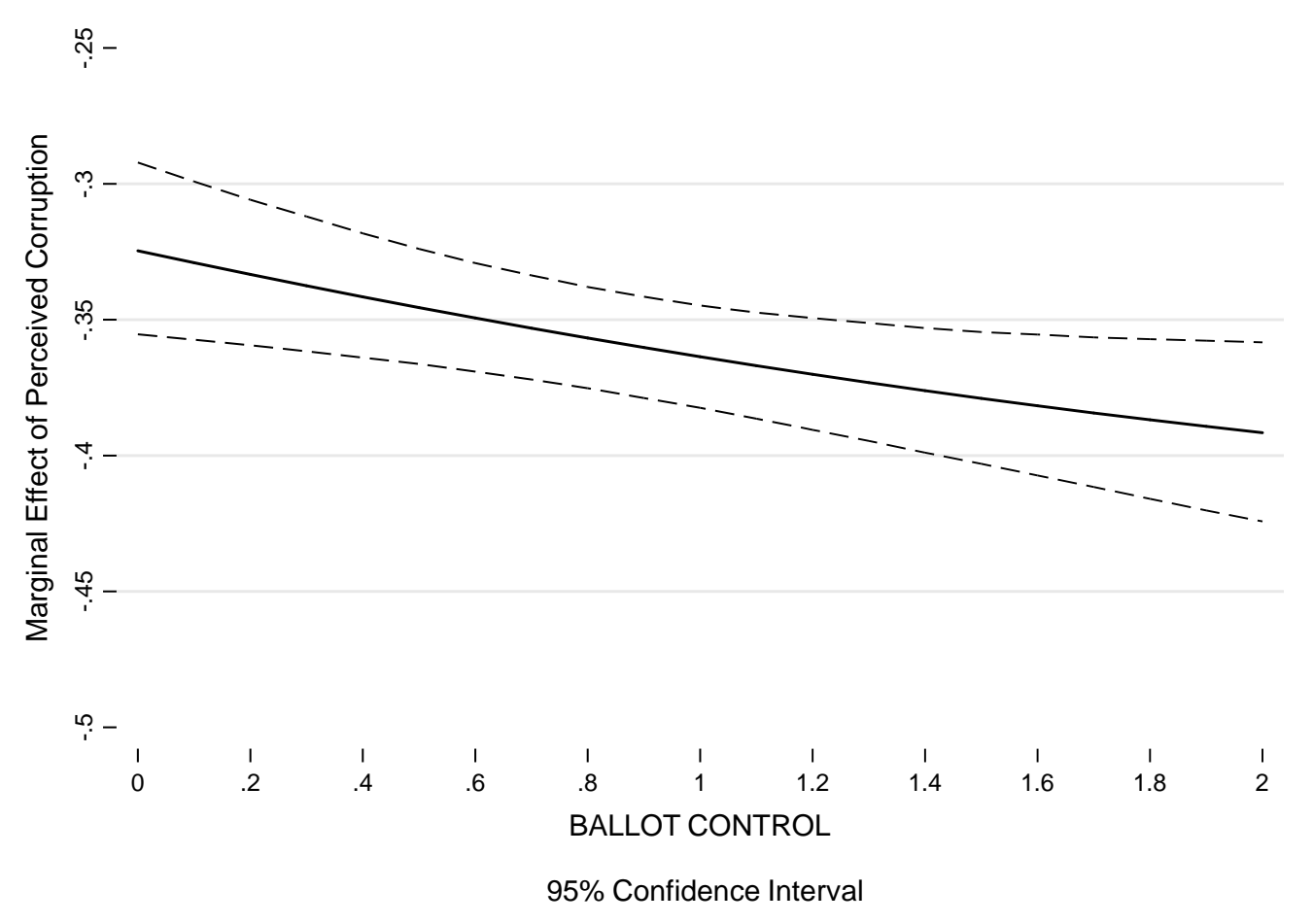

Figure 4 Marginal effect of corruption on satisfaction with democracy, as ballot control increases.

Note: Dependent variable is the probability of being fairly or very satisfied with democracy 